[Agr. Biol. Chem., Vol. 36, No. 13, p. 2539 2546, 1972]

\title{
Synthesis of Kaurane Derivatives with an Oxygen Function in Ring $A^{\dagger}$
}

\author{
By Masao Shlozaki, ${ }^{*}$ Kenji Mori and Masanao Matsui \\ Department of Agricultural Chemistry, The University of Tokyo, \\ Bunkyo-ku, Tokyo 113
}

Received July 29, 1972

\begin{abstract}
A total synthesis of some kaurane derivatives with an oxygen function in ring $\mathrm{A}$ was accomplished. They are potential intermediates for the synthesis of highly oxygenated diterpenes such as grayanotoxins.
\end{abstract}

Our continuing efforts in the synthesis of biologically active diterpenes resulted in the total syntheses of $( \pm)$-kaur-16-en-19-oic acid, ${ }^{1}$ (土)-gibberellins $A_{2}, A_{4}, A_{9}$ and $A_{10},{ }^{2)}( \pm)$ steviol $^{31}$ and other polycyclic natural products. However, highly oxygenated diterpenes such as phorbol and grayanotoxins remain as utmost difficult synthetic objectives. We have chosen the grayanotoxins as our target in view
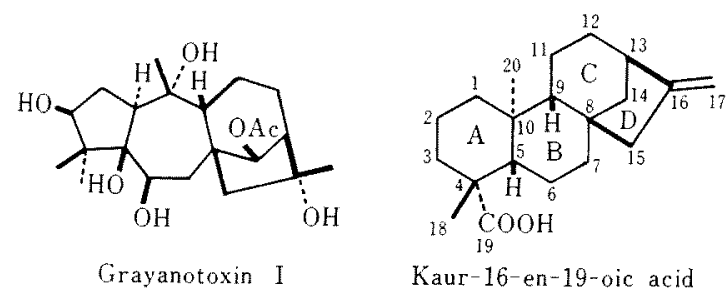

of their insecticidal activity. This paper describes in detail our preliminary endeavor along this line aiming at the synthesis of suitable kaurane derivatives with an oxygen

$\dagger$ Diterpenoid Total Synthesis, Part XX. Part XIX, K. Mori, Y. Nakahara and M. Matsui, Tetrahedrom, 28, 3217 (1972). Although the formulas depicted in this paper represent only one enantiomer, they are taken to mean a racemate in the cases of synthetic compounds.

* Experimental part of this work was taken from the doctoral dissertation of M.S., March, 1971. Present address: Central Research Laboratories, Sankyo Co., Ltd., Hiromachi, Shinagawa-ku, Tokyo 140. function in ring $A$. One of them served as a key intermediate in our photochemical synthesis of compounds with grayanotoxin skeleton. ${ }^{4}$ The present synthetic route is essentially similar to that employed by us in the synthesis of (土)-kaur-16-en-19-oic acid.

The Robinson annelation of a tetralone (I) ${ }^{5}$ with ethyl vinyl ketone or methyl vinyl ketone afforded racemic tricyclic enones IIa and IIb, ${ }^{6}$, respectively. They were converted to phenols III a and IIIb with hydriodic acid. Catalytic hydrogenation " of IIIa gave a mixture of $\mathrm{A} / \mathrm{B}$ cis and trans compounds, while the Birch reduction of IIIa and $I I I b$ yielded only $A / B$ trans alcohols, IVa and IVb, with an equatorial hydroxyl group at $\mathrm{C}-3$. $^{\text {") }}$ Then the ring $\mathrm{A}$ hydroxyl group was protected as an acetate by acetylation of IVa and IVb with methyl acetate in the presence of $p$-toluenesulfonic acid to give $\mathrm{Va}$ and $\mathrm{Vb}$. They were hydrogenated over Raney nickel $\mathrm{T}-1$ and the resulting alcohols were oxidized with the Jones chromic acid to give ketones VIa and VIb. In the case of the oxidation of $\mathrm{Va}$, a small amount of a diketone VIIa was obtained as a by-product.

In order to introduce an allyl group at C-8, the $\mathrm{C}-13$ methylene group of VI was protected by $n$-butylthiomethylene group ${ }^{21}$ in the usual manner to give VIII. During this process 


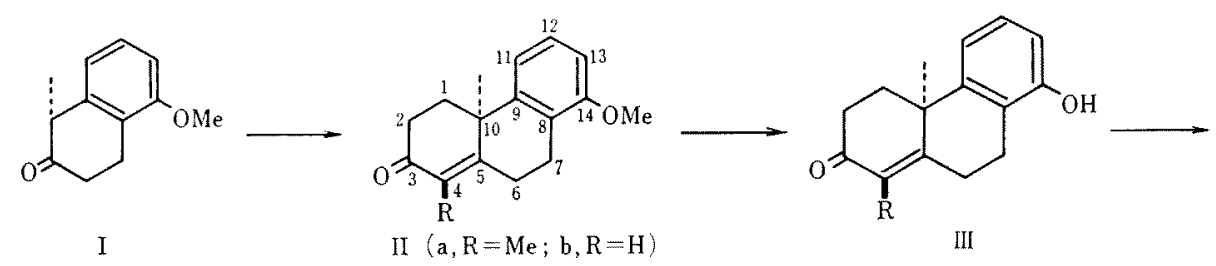<smiles>[R]C1[C@H](O)CC[C@]2(C)c3cccc(O)c3CC[C@H]1[C@]2(C)CC</smiles>

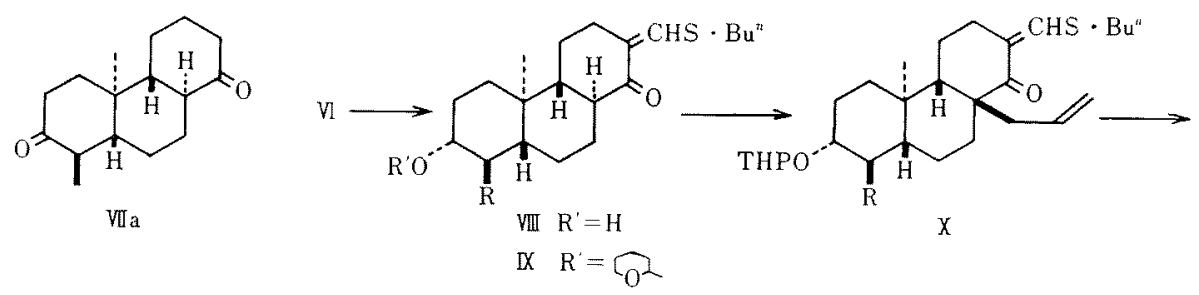

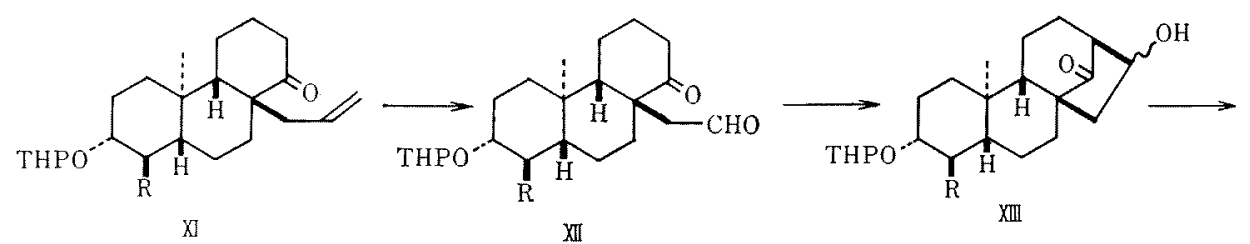

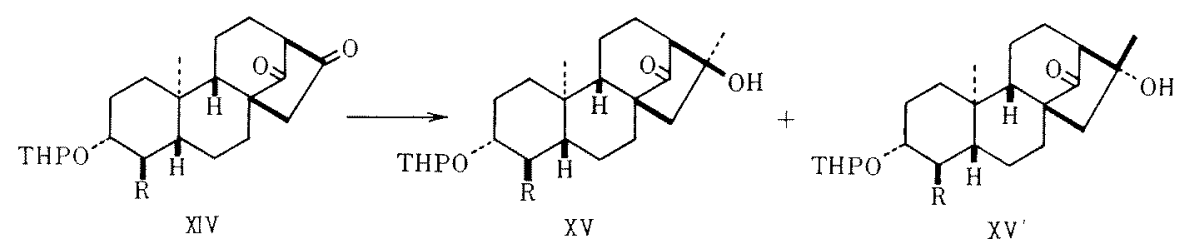

the acetoxyl group at $\mathrm{C}-3$ was hydrolyzed to a hydroxyl group. Hence this was protected as a tetrahydropyranyl ether as in IX. Treatment of the ketones IXa and IXb with potassium tert-butoxide and allyl bromide afforded $\mathrm{B} / \mathrm{C}$ cis-fused alkylated products, $\mathrm{Xa}$ and $\mathrm{Xb}{ }^{c f .1)}$ The blocking group at $\mathrm{C}-8$ of $\mathrm{X}$ was removed by alkaline hydrolysis yielding XI. The allylated ketones XIa and XIb were treated with osmium tetroxide and sodium periodate $^{10}$ to give aldehydes XIIa and XIIb, respectively.
The aldol-type ring closure of these keto aldehydes by treatment with sodium methoxide afforded tetracyclic ketols, XIIIa and XIIIb. They were converted to diketones XIVa and XIVb by the Sarett oxidation with chromic anhydride-pyridine.

The 17-methyl group was introduced by the Grignard reaction of the diketone XIV with methyl magnesium iodide to give two ketols $\mathrm{XV}$ and $\mathrm{XV}^{\prime}$ in the ratio of $10: 1$ (in the $a$ series) or $7: 1$ (in the $b$ series). The configuration at $\mathrm{C}-16$ was assigned on the following 

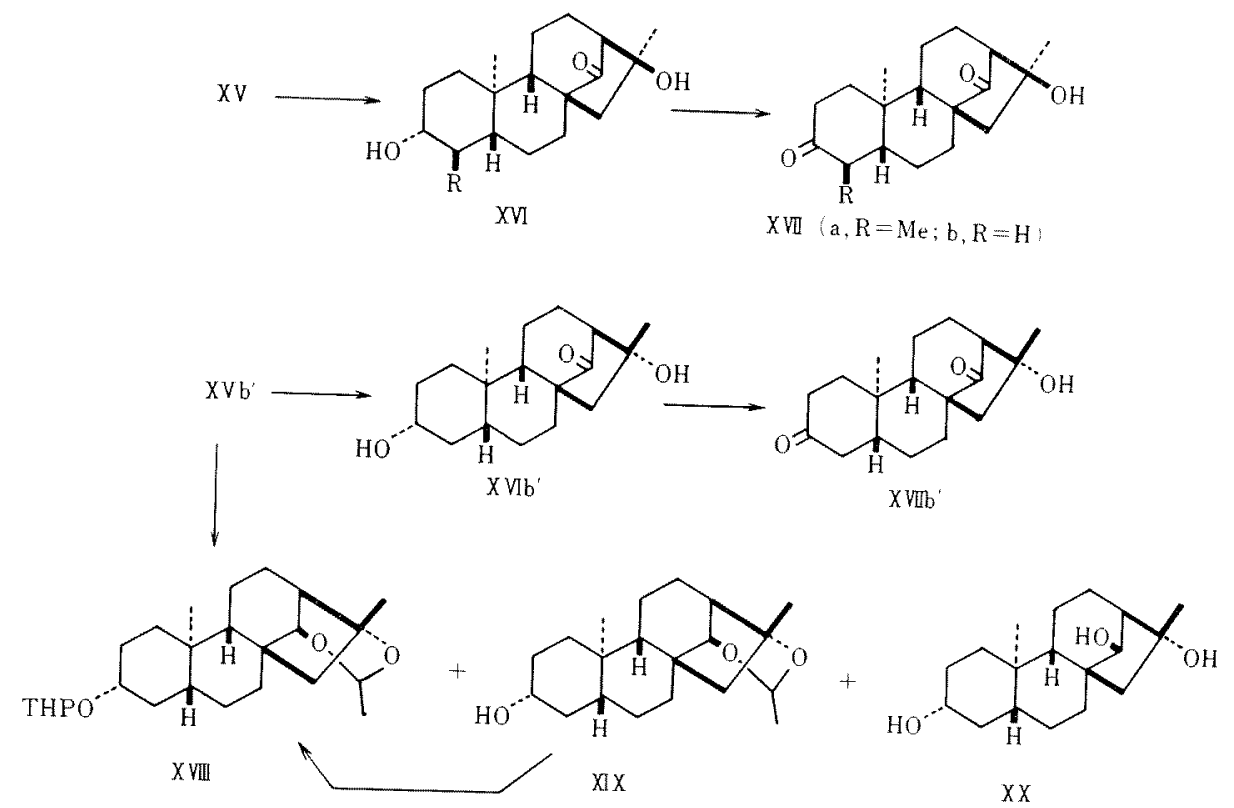

basis. The minor ketol $\mathrm{XVb}^{\prime}$ was reduced with lithium in liquid ammonia to give an oily diol. This was treated with acetaldehyde in the presence of anhydrous zinc chloride to give two ethylidene derivatives, XVIII and XIX. The formation of the latter was obviously due to the hydrolytic removal of the tetrahydropyranyl protective group during the process. On the other hand, the major ketol $\mathrm{XVb}$ did not yield any ethylidene derivative when treated in the same manner as for $\mathrm{XVb}^{\prime}$. Inspection of a molecular model indicated that the diol derived from $\mathrm{XVb}^{\prime}$ could afford an ethylidene derivative while that from $X V b$ could not. The above result also suggests stereostructure XVa for the major ketol of $a$ series, although no attempt was made to prepare an ethylidene derivative from $\mathrm{XVa}^{\prime}$.

The tetrahydropyranyl protective group of $X V$ was removed in the usual manner to give XVI. These two diols XVIa and XVIb were oxidized with the Jones chromic acid to diketones XVIIa and XVIIb, respectively. These two diketones are potential intermediates for the synthesis of oxygenated diterpenes. The conversion of the kaurane XVIIb to compounds with grayanotoxin skeleton will be published soon in full detail.

\section{EXPERIMENTAL}

All mp's are uncorrected.

(1)-3-Oxo-4, 10-dimethyl-14-methoxy-1,2, 3,6, 7, 10hexalydrophenanthene (I/a). To a stirred solution of $\mathrm{KOH}(20 \mathrm{~g})$ in $\mathrm{MeOH}(340 \mathrm{ml})$ and water $(35 \mathrm{ml})$, $\mathrm{I}(48.6 \mathrm{~g})$ was added at $0^{\circ} \mathrm{C}$ under nitrogen atmosphere. The mixture was cooled at $-20 \sim-15^{\circ} \mathrm{C}$, and ethyl vinyl ketone $(25.5 \mathrm{~g})$ was added slowly. After $1.5 \mathrm{hr}$ cooling bath was removed and stirring was continued overnight at room temperature. The resulting precipitates were filtered and washed with water, small amount of $\mathrm{MeOH}$ and ether to give $30 \mathrm{~g}$ of $11 \mathrm{a}$. The mother liquor was neutralized with dil $\mathrm{HCl}$ aq and extracted with AcOEt. The extract was washed with water and dried $\left(\mathrm{MgSO}_{4}\right)$. Evaporation of EtOAc gave an oil. This was distilled to afford $6.0 \mathrm{~g}$ of IIa: bp $167^{\circ} \mathrm{C}$ $(0.06 \mathrm{mmHg})$, (total $36 \mathrm{~g}, 55 \%)$. Recrystallization from $\mathrm{EtOH}$ gave prisms, $\mathrm{mp} 137.5 \sim 138.5^{\circ} \mathrm{C}$. $\nu_{\text {max }}$ (Nujol) $1650,1620,1585,1268,1155 \mathrm{~cm}^{\cdots 1}$ NMR (100 $\left.\mathrm{MHz}_{2} \mathrm{CDCl}_{3}\right)=2.75 \sim 3.40(3 \mathrm{H}), 6.22(2 \mathrm{H}, \mathrm{s}), 8.17(3 \mathrm{H}$, s) $8.47(3 \mathrm{H}, \mathrm{s}), 6.6 \sim 8.3(8 \mathrm{H}, \mathrm{m})$. Anal. Found: $\mathrm{C}$, 
79.50; H, 7.77. Calcd. for $\mathrm{C}_{17} \mathrm{H}_{20} \mathrm{O}_{2}: \quad$ C, 79.65; H, $7.86^{\circ} \circ$

(4)-3-0xo-10-methy-14-methoxy-1, 2, 3, 6, 7, 10herahydrophenanthrene (IIb). The same treatment as described above of I with methyl vinyl ketone gave IIb, in $50 \%$ yield, bp $175^{\circ} \mathrm{C}(0.1 \mathrm{mmHg})$ (lit. ${ }^{5)}$ bp $\left.180^{\circ} \mathrm{C}(0.1 \mathrm{mmHg})\right)$, mp $122.5 \sim 123.5^{\circ} \mathrm{C} . \quad \nu_{\mathrm{m}: \mathrm{x}}$ (Nujol) $1654,1625,1585,1265,1066 \mathrm{~cm}^{-1} \quad$ NMR $(100 \mathrm{MHz}$, $\left.\mathrm{CDCl}_{3}\right) \quad 2.753 .90(3 \mathrm{H}, \mathrm{t}, \mathrm{d}, \mathrm{d}), 4.12(1 \mathrm{H}, \mathrm{s}), 6.19$ $(3 \mathrm{H}, \mathrm{s}), 8.43(3 \mathrm{H}, \mathrm{s})$. Anal. Found: $\mathrm{C}, 79.21 ; \mathrm{H}$, 7.43. Calcd. for $\mathrm{C}_{10} \mathrm{H}_{18} \mathrm{O}_{2}: \mathrm{C}, 79.31 ; \mathrm{H}, 7.49 \%$.

(4)-3-0xo-10-methyl-14-hydroxy-1, 2, 3, 6, 7, 10-hexahydrophenanthene (IIJ). III was obtained in $52.3 \%$ yield ( $45 \%$ recovery) by the same procedure which was described in Ref. 5).

$(-5)-3-0 \times 0-4,10$-dimethyl-14-hydroxy-1,2,3,6, 7, 10hexalydrophenanthene (IIIa). Ila was worked up as described above to give IIIa in $80 \%$ yield which was recrystallized from benzene, mp 212 214 C. $\Sigma_{\text {mis }}$ (Nujol) $3360,1648,1619,1581,1000 \mathrm{~cm}^{-1}$. Anal. Found: $\mathrm{C}, 79.16 ; \mathrm{H}, 7.40$. Calcd. for $\mathrm{C}_{16} \mathrm{H}_{18} \mathrm{O}_{2}$ : C, $79.31 ; \mathrm{H}, 7.49 \%$.

( )-3n,1t-Dihydroxy-10n-methyl-1,2,3, 4,5, 6,7,10octahydrophenanthrenc $(/ \mathrm{V} b)$. To a solution of liq $\mathrm{NH}_{3}$ (1 liter) and $\mathrm{Li}$ (20 g), IIIb (57 g) in THF (1 liter) was added with stirring at $-40 \sim-45^{\circ} \mathrm{C}$. After $1 \mathrm{hr}$ $\mathrm{NH}_{4} \mathrm{Cl}(170 \mathrm{~g})$ was cautiously added in small portions at $-40--45^{\circ} \mathrm{C}$. After the evaporation of $\mathrm{NH}_{3}$ at room temperature, the residue was acidified with cooled $\mathrm{HCl}$ aq. (conc $\mathrm{HCl}-\mathrm{H}_{3} \mathrm{O}=1: 1$ ) and extracted with ether. The extract was washed with water and dried $\left(\mathrm{Na}_{2} \mathrm{SO}_{4}\right)$. After treatment with activated charcoal, the ether layer was evaporated to give an oil $(60 \mathrm{~g})$. This oil was chromatographed on silica gel $(1.1 \mathrm{~kg})$ and eluted with benzene-EtOAc (9:1) to afford crystals $(47.5 \mathrm{~g})$ of IVb in $82 \%$ yield. 2 mux (Nujol) $3500,3240,1582,1266,1042 \mathrm{~cm}^{-1}$ This was employed for the next reaction without further purification.

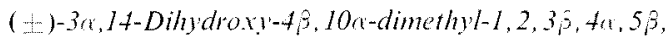
6,7,10-octahydrophenanthene (IVa). IIla was worked up as described above to afford IVa quantitatively. $\nu_{m a x}$ (Nujol) 3460 (b), 1583, 1267, 1020, 1010, 996, $925,900 \mathrm{~cm}^{-1}$. This was employed for the next reaction without further purification.

$( \pm)-3 \alpha-$ Aceto $x y-4,10 \alpha$-dimethy/-14-hydroxy-1,2,38,$4 a, 5 \hat{\beta}, 6,7,10$-octahydrophenanthrene ( $\mathrm{Va}$ ). A solution of diol IVa $(0.93 \mathrm{~g})$ and $p$-TsOH $(2.8 \mathrm{~g})$ in MeOAc $(180$ ml) was heated under reflux for $4.5 \mathrm{hr}$, then cooled, and washed with dil. $\mathrm{NaHCO}_{3}$ aq. and brine, and dried $\left(\mathrm{Na}_{2} \mathrm{SO}_{4}\right)$. Evaporation of MeOAc gave crystals $(0.95 \mathrm{~g})$ in $87.2 \%$ yield. Recrystallization from EtOAc-EtOH $(9: 1)$ gave prisms, mp $170 \sim 1744^{\circ} \mathrm{C}$. $\nu_{\text {in: } x}$ (Nujol) $3464,1711,1582,1276,976 \mathrm{~cm}^{-1}$. NMR $\left.\left(100 \mathrm{MHz}^{\mathrm{CDCl}}\right)_{3}\right)=2.80 \sim 3.45(3 \mathrm{H}, \mathrm{m}), 5.14(1 \mathrm{H}, \mathrm{m})$, $7.92(3 \mathrm{H}, \mathrm{s}), 8.86(3 \mathrm{H}, \mathrm{s}), 9.06(3 \mathrm{H}, \mathrm{d}, J=6 \mathrm{~Hz})$. Anal. Found: $\mathrm{C}, 75.25 ; \mathrm{H}, 8.10$. Calcd. for $\mathrm{C}_{18} \mathrm{H}_{24} \mathrm{O}_{3}$ : C, $74.97 ; \mathrm{H}, 8.39 \%$.

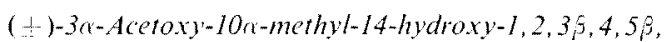
6.7.10-octahydrophenanthene ( $/ \mathrm{b}) . \quad$ IVb $(25 \mathrm{~g})$ was worked up as described above to give crystals $(21 \mathrm{~g})$ in $71 \%$ yield. Recrystallization from EtOH-EtOAc (1:9) gave prisms, mp $186 \sim 187^{\circ} \mathrm{C}$. $\nu_{\max }$ (Nujol) $3410,1695,1585,1035 \mathrm{~cm}^{-1} \quad$ NMR $\left(100 \mathrm{MHz}^{-\mathrm{CDCl}_{3}}\right)$ $2.90 \sim 3.45(3 \mathrm{H}, \mathrm{d}, \mathrm{t}, \mathrm{d}), 5.23(1 \mathrm{H}, \mathrm{m}), 7.94(3 \mathrm{H}, \mathrm{s})$, $8.87(3 \mathrm{H}$, s). Anal. Found: $\mathrm{C}, 74.10 ; \mathrm{H}, 7.92$. Calcd. for $\mathrm{C}_{17} \mathrm{H}_{22} \mathrm{O}_{3}$ : C, $74.42 ; \mathrm{H}, 8.08 \%$.

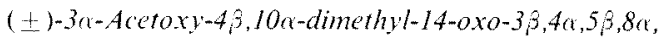
9-perhydrophenanthrene (VIa). The phenol Va $(15$ g) in $99 \%$ EtOH $(120 \mathrm{ml})$ was hydrogenated over Raney nickel $(\mathrm{T}-1)(15 \mathrm{~g})$ at $180^{\circ} \mathrm{C}$ and an initial pressure of $90 \mathrm{~kg} / \mathrm{cm}^{2}$ for $3 \mathrm{hr}$. Removal of the catalyst and the solvents gave an oily mixture which was dissolved in acetone $(400 \mathrm{ml})$. To this stirred solution, Jones chromic acid reagent $(35 \mathrm{ml}$ ) was added dropwise at $0 \sim 5^{\circ} \mathrm{C}$, and the mixture left to stand at room temperature for $20 \mathrm{~min}$. $\mathrm{MeOH}$ was added to destroy the excess of the oxidant. After removal of the solvents in vacuo, the residue was diluted with water and extracted with EtOAc. The extract was washed with $\mathrm{NaHCO}_{3}$ aq., dried $\left(\mathrm{Na}_{2} \mathrm{SO}_{4}\right)$, and concentrated in vacto. Trituration of the residue with ether-n-hexane gave $8.0 \mathrm{~g}$ of the product. The filtrate was chromatographed on alumina $(140 \mathrm{~g})$ to afford another VIa $(2.2 \mathrm{~g}, 67 \%$ in total) and diketone VIla $(1.03 \mathrm{~g}, 6.8 \%)$ by the elution with benzene- $n$-hexane $(1: 1)$. VIa was recrystallized from ether-n-hexane, mp $140 \sim 143^{\circ} \mathrm{C}$. $\nu_{\text {max }}$ (Nujol) 1734, 1695, $1250 \mathrm{~cm}^{-1} \quad$ NMR (100 MHz, $\left.\mathrm{CDCl}_{3}\right)=5.69(1 \mathrm{H}, \mathrm{d}, \mathrm{d}, \mathrm{d}, J=11,11,5 \mathrm{~Hz}), 7.97(3 \mathrm{H}$, s), $9.08(3 \mathrm{H}, \mathrm{s}), 9.17(3 \mathrm{H}, \mathrm{d}, J=6 \mathrm{~Hz})$. Anal. Found: C, 74.20; H, 9.54. Calcd. for $\mathrm{C}_{18} \mathrm{H}_{28} \mathrm{O}_{3}:$ C, 73.93; $\mathrm{H}, 9.65 \%$. VIIa was recrystallized from ether, mp $102 \sim 103^{\circ} \mathrm{C} . \nu_{\max }$ (Nujol) $1706 \mathrm{~cm}^{-1}$ NMR (100 $\left.\mathrm{MHz} \mathrm{CDCl}_{3}\right) \quad 8.81(3 \mathrm{H}, \mathrm{s}), 8.98(3 \mathrm{H}, \mathrm{d}, J=6 \mathrm{~Hz})$. Anal. Found: $\mathrm{C}, 77.14 ; \mathrm{H}, 9.64$. Calcd for $\mathrm{C}_{16} \mathrm{H}_{24} \mathrm{O}_{2}$ : $\mathrm{C}, 77.37 ; \mathrm{H}, 9.74 \%$.

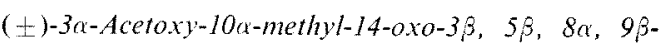
perhydrophenanthrene $(\mathrm{VI} b)$. The phenol $\mathrm{Vb}(60 \mathrm{~g})$ 
was worked up as described above to obtain $41.8 \mathrm{~g}$ $(68.3 \%)$ of the product. This was recrystallized from ether, $\operatorname{mp} 130 \sim 131^{\circ} \mathrm{C} . \nu_{\max }$ (Nujol) 1724, 1700, $1240,1035 \mathrm{~cm}^{-1}$. NMR $\left(100 \mathrm{MHz}, \mathrm{CDCl}_{3}\right) \quad 5.38$ $(1 \mathrm{H}, \mathrm{m}), 8.03(3 \mathrm{H}, \mathrm{s}), 9.14(3 \mathrm{H}, \mathrm{s})$. Anal. Found: $\mathrm{C}, 73.42 ; \mathrm{H}, 9.19$. Caled for $\mathrm{C}_{17} \mathrm{H}_{26} \mathrm{O}_{33}$ : C, 73.34; $\mathrm{H}, 9.41 \%$.

$( \pm)-3 \alpha-H y d r o x y-10 \alpha-m e t h y l-13-n-b u t y$ thiomethylene14-oxo-3 $\beta, 5 \beta, 8 \alpha, 9 \beta$-perhydrophenanthrene(VIIIb). The ketone VIb $(1.6 \mathrm{~g})$ in dry THF $(40 \mathrm{ml})$ was added to a stirred suspension of powdered $\mathrm{NaOMe}(1.5 \mathrm{~g})$ in dry benzene $(25 \mathrm{ml})$. To the ice-cooled mixture, redistilled ethyl formate $(4 \mathrm{ml})$ was added with stirring. The mixture was left to stand overnight at room temperature. It was poured into ice-water $(25 \mathrm{ml})$ and aqueous layer was separated. The organic layer was diluted with ether and extracted with $5 \% \mathrm{NaOH}$ aq. $(15 \mathrm{ml} 3)$. The combined aqueous solution was acidified with dil. $\mathrm{HCl}$ at $0 \sim 5^{\circ} \mathrm{C}$ and rapidly extracted with EtOAc. The extract was washed with water, dried $\left(\mathrm{MgSO}_{4}\right)$ and concentrated to give $1.7 \mathrm{~g}$ of the oily product. This formylated ketone $(1.7 \mathrm{~g})$ dissolved in dry benzene $(50 \mathrm{ml})$ was mixed with $n$-butyl mercap$\tan (0.8 \mathrm{ml})$ and $p-\mathrm{TsOH}(20 \mathrm{mg})$. The mixture was heated under refux for $4 \mathrm{hr}$ and poured into water. The benzene layer was separated and aqueous layer was extracted with ether. The combined extract was washed with water and brine, dried $\left(\mathrm{MgSO}_{4}\right)$ and concentrated in vacuo to give an oily product. This oil was chromatographed on alumina $(30 \mathrm{~g})$. The elution with benzene gave $1.62 \mathrm{~g}(83.5 \%)$ of VIIIb, $\operatorname{mp} 114 \sim 115^{\circ} \mathrm{C} . \nu_{\max }$ (Nujol) $3560,1642,1530$, $1305,1078,1063,832,784 \mathrm{~cm}^{-1}$ NMR $(100 \mathrm{MHz}$, $\left.\mathrm{CDCl}_{3}\right)=2.52(1 \mathrm{H}, \mathrm{s}), 6.40(1 \mathrm{H}, \mathrm{m}), 7.17(2 \mathrm{H}, \mathrm{t}, J=$ $7 \mathrm{~Hz}), 7.75\left(1 \mathrm{H}, \mathrm{s}, \mathrm{D}_{2} \mathrm{O}\right.$ exchanged), $9.08(3 \mathrm{H}, \mathrm{t}, J=$ $7 \mathrm{~Hz}), 9.19(3 \mathrm{H}, \mathrm{s})$. Anal. Found: C, 71.81; $\mathrm{H}$, 9.17; S, 9.37. Calcd. for $\mathrm{C}_{20} \mathrm{H}_{32} \mathrm{O}_{2} \mathrm{~S}:$ C, $71.39 ; \mathrm{H}$, $9.59 ; \mathrm{S}, 9.51 \%$.

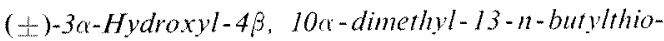

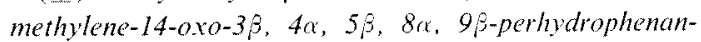
threne (VIIIa). The ketone VIa $(1.6 \mathrm{~g})$ was worked up as described above to afford $1.15 \mathrm{~g}$ of crystals, mp $54 \sim 57^{\circ} \mathrm{C} . \quad \nu_{\max }$ (Nujol) $3360,1640,1550,1325$, $1195,1073,790 \mathrm{~cm}^{-1}$ NMR (100 MHz, $\left.\mathrm{CDCl}_{3}\right)$ $-2.25(1 \mathrm{H}, \mathrm{bs}), 6.93(1 \mathrm{H}, \mathrm{d}, \mathrm{t}), 7.22(2 \mathrm{H}, \mathrm{t}, J=6 \mathrm{~Hz})$. Anal. Found: C, 72.24; H, 9.57; S, 8.89. Calcd. for $\mathrm{C}_{21} \mathrm{H}_{34} \mathrm{O}_{2} \mathrm{~S}: \quad \mathrm{C}, 71.96 ; \mathrm{H}, 9.78 ; \mathrm{S}, 9.13 \%$.

$( \pm)-3 a-T e t r a h y d r o p y r a n y l o x y-10 a-m e t h y l-13-n-b u t y l-$

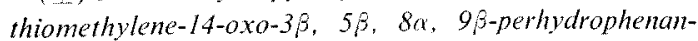
threne $(I X b)$. A solution of VIIIb $(32 \mathrm{~g})$ in dry ben- zene $(750 \mathrm{ml})$ was mixed with dihydropyrane $(100 \mathrm{ml})$ and $p$-toluenesulfonic acid $(750 \mathrm{mg})$ and stirred for $6 \mathrm{hr}$ at room temperature. Then the solution was washed with $\mathrm{NaHCO}_{3}$ aq., dried $\left(\mathrm{Na}_{2} \mathrm{SO}_{4}\right)$ and concentrated in vacuo. Chromatography on alumina $(600 \mathrm{~g})$ of the residue eluted with benzene gave $36 \mathrm{~g}$ $(90 \%)$ of crystals. $\nu_{m: x}$ (Nujol) $1655,1550,1060,1030$, $972 \mathrm{~cm}^{-1}$. This was employed for the next step without further purification.

( \pm$)-3 \alpha-T e t r a h y d r o p y r a n y l o x y-4 \beta, 10 \alpha-$ dimethyl-13-n-

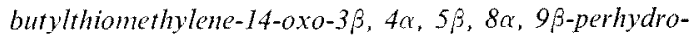
phenanthrene $(I X a)$. The alcohol VIIlla was worked up as described above. The crystalline IXa was obtained in $90 \%$ yield and recrystallized from ether, mp $128 \sim 130^{\circ} \mathrm{C}$. $\nu_{\text {的 a }}$ (Nujol) $1658,1556,1040,993 \mathrm{~cm}^{-1}$. NMR $\left(100 \mathrm{MHz}, \mathrm{CDCl}_{3}\right) \tau 5.0 \sim 6.6(4 \mathrm{H}), 2.53(1 \mathrm{H}$, bs), $7.21(2 \mathrm{H}, \mathrm{t}, J=7 \mathrm{~Hz})$. Anal. Found: C, 71.85; $\mathrm{H}, 9.74 ; \mathrm{S}, 7.37$. Calcd. for $\mathrm{C}_{26} \mathrm{H}_{42} \mathrm{O}_{3} \mathrm{~S}$ : C, 71.85; $\mathrm{H}, 9.73 ; \mathrm{S}, 7.31 \%$.

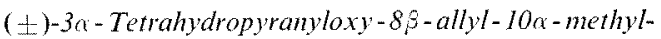

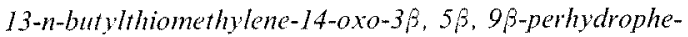
nanthrene $(X b)$. To a stirred and ice-cooled solution of $\mathrm{t}$-BuOK (from $23 \mathrm{~g} \mathrm{~K}$ ) in $\mathrm{t}-\mathrm{BuOH}(700 \mathrm{ml}$ ), $\mathrm{IXb}(45 \mathrm{~g})$ dissolved in dry benzene $(600 \mathrm{ml})$ was added under $\mathrm{N}_{2}$ atmosphere. After $10 \mathrm{~min}$ stirring, allyl bromide $(110 \mathrm{ml})$ was rapidly added with stirring. Ice-cooling was continued for 10 min after the addition. Then the mixture was heated under reflux for $2 \mathrm{hr}$. During this period an additional amount of allyl bromide $(50 \mathrm{ml})$ was added. After cooling, the mixture was poured into dil. $\mathrm{NaHCO}_{3}$ aq. and extracted with ether. The extract was washed with brine, dried $\left(\mathrm{Na}_{2} \mathrm{SO}_{4}\right)$ and concentrated in vacuo to give an oil (49 g). $\nu_{\max }(\mathrm{film}), 3100$ (w) $, 1660,1550,1032,920 \mathrm{~cm}^{-1}$. This was employed for the next reaction without further purification.

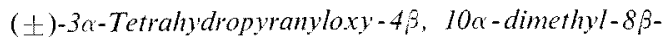

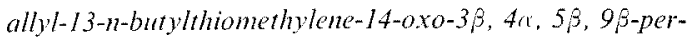
hydrophenanthrene $(X a)$. The pyranyl ether IXa was worked up as described above. The oily product $\mathrm{Xa}$ was obtained in $92 \%$ yield. $\nu_{m, x}$ (film) $3060(w)$, $1663,1545,1078,1025,970,916 \mathrm{~cm}^{-1}$. This was employed for the next reaction without further purification.

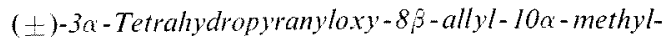

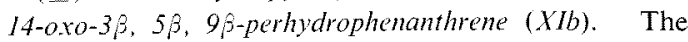
oily $\mathrm{Xb}(49 \mathrm{~g})$ dissolved in $95 \% \mathrm{EtOH}(600 \mathrm{ml})$ was mixed with $\mathrm{KOH}(50 \mathrm{~g})$ in water $(250 \mathrm{ml})$. The mixture was heated under reflux for $32 \mathrm{hr}$ under $\mathrm{N}_{2}$ at- 
mosphere. EtOH was removed in vacuo and the residue was extracted with ether. The extract was washed with water followed by brine, dried $\left(\mathrm{MgSO}_{4}\right)$ and concentrated to give $35 \mathrm{~g}$ (two steps overall yield $90.5 \%$ ) of crystalline XIb which was recrystallized from $n$-hexane as needles, mp $92 \sim 94 \mathrm{C}$. $\nu_{\mathrm{max}}$ (Nujol) $3100(w), 1698,1639(w), 1030,990,914 \mathrm{~cm}^{-1} \quad$ NMR $\left(100 \mathrm{MHz}, \mathrm{CDCl}_{3}\right)=4.50(1 \mathrm{H}, \mathrm{m}), 4.90 \sim 5.35(2 \mathrm{H}$ $1 \mathrm{H}, \mathrm{m}), 6.16(1 \mathrm{H}, \mathrm{m}), 6.52(2 \mathrm{H}, \mathrm{m}), 9.19(3 \mathrm{H}, \mathrm{s})$. Anal. Found: $\mathrm{C}, 76.98 ; \mathrm{H}, 9.65$. Calcd. for $\mathrm{C}_{23} \mathrm{H}_{36} \mathrm{O}_{3}$ : C, $76.62 ; \mathrm{H}, 10.07 \%$.

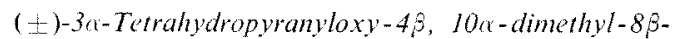

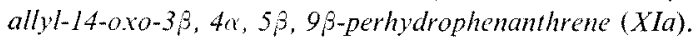
$X a$ was worked up as described above to give an oil (XIa) in $98 \%$ yield. $\nu_{\max }$ (film), $3090(\mathrm{w}), 1698,1635$ (w), 1080, 1035, 970, 915 $\mathrm{cm}^{-1}$. NMR $(100 \mathrm{MHz}$, $\left.\mathrm{CDCl}_{3}\right) \div 4.50(1 \mathrm{H}, \mathrm{m}), 4.95 \sim 5.48(2 \mathrm{H}+1 \mathrm{H}, \mathrm{m})$, $6.10 \sim 6.60(3 \mathrm{H}, \mathrm{m}), 9.21(3 \mathrm{H}, \mathrm{s})$. This was employed for the next reaction without further purification.

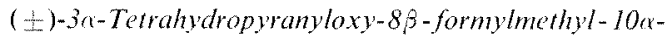

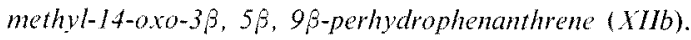
$\mathrm{OsO}_{4}(630 \mathrm{mg})$ was added to a stirred solution of XIb $(35 \mathrm{~g})$ in THF $(630 \mathrm{ml})$ and water $(200 \mathrm{ml})$ under $\mathrm{N}_{2}$ atmosphere. After stirring $10 \mathrm{~min}$, powdered sodium metaperiodate $(63 \mathrm{~g}$ ) was added under cooling by water, and stirring was continued for $15 \mathrm{hr}$ at room temperature. The mixture was diluted with ether. The ether solution was washed with water and brine, dried ( $\mathrm{Na}_{2} \mathrm{SO}_{4}$ ) and evaporated to give $34 \mathrm{~g}$ of an oil (XIIb). $\nu_{\mathrm{m} \text { ix }}$ (film), $2800(\mathrm{w}), 1720,1705,1130,1040,990,920$ $\mathrm{cm}^{-1}$. This was employed for the next reaction without further purification.

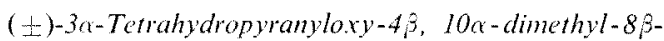
formylmethyl-14-oxo-3, 4a, 5,3, 9,-perhydrophenanthrene $(X I I a)$. The ketone XIa worked up as described above to give an oil $(95 \%)$ of XIIa, $\nu_{\mathrm{max}}$ (film), 2790 (w) $1710,1692,1075,1025,970 \mathrm{~cm}^{-1}$ This was employed for the next reaction without further purification.

$( \pm) 3 a-T e t r a h y d r o p y r a n y l o x y-14-0 x 0-16 \xi-h y d o x y-17$, 18.19-trishorkaurane $(X I I I b)$. The oily aldehyde XIIb $(52 \mathrm{~g})$ dissolved in THF $(750 \mathrm{ml})$ was added to a solution of $\mathrm{NaOMe}$ (from $20 \mathrm{~g} \mathrm{Na}$ ) in $\mathrm{MeOH}$ (1 liter). The mixture was refluxed for $2 \mathrm{hr}$ under $\mathrm{N}_{2}$ atmosphere. After concentration in vacuo, the residue was diluted with water and extracted with ether. The ether extract was washed with water and brine, dried $\left(\mathrm{Na}_{2} \mathrm{SO}_{4}\right)$ and concentrated in vacuo to give $46 \mathrm{~g}$ of crude crystals. $\nu_{\text {o a }}$ (Nujol) $3340,1730,1123,1032,980 \mathrm{~cm}^{-1}$
This was employed for the next reaction without further purification.

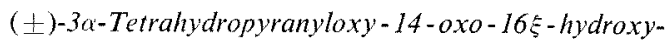
17,19-bisnorkaurane (XIIIa). XIIa was worked up as described above to give crude crystals $(65 \%)$. $\nu_{\text {max }}$ (Nujol) $3300,1743,1120,1030,980 \mathrm{~cm}^{-1}$. This was employed for the next reaction without further purification.

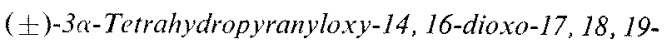
trisnorkaurane $(X I V b)$. To a solution of chromic anhydride-pyridine complex $(750 \mathrm{ml}$ of pyridine and $60 \mathrm{~g}$ of $\mathrm{CrO}_{3}$ ), the crude alcohol XIIIb (46 $\mathrm{g}$ ) in dry pyridine $(500 \mathrm{ml})$ was added with stirring at $15 \sim 20^{\circ} \mathrm{C}$. The reaction mixture was stirred overnight at room temperature and poured into dil. $\mathrm{NaHCO}_{3}$ aq. (2 liters) and extracted with ether. The extract was washed with water and brine, and dried $\left(\mathrm{Na}_{2} \mathrm{SO}_{4}\right)$. The ether solution was evaporated to give crude crystals. Tritulation of these crystals with ether-pet. ether gave $23 \mathrm{~g}$ of the product and the residual oily mixture was chromatographed on alumina to give further amount of $\mathrm{XIVb}(5.6 \mathrm{~g})$. Recrystallization from benzene- $n$ hexane gave needles, mp $146 \sim 148^{\circ} \mathrm{C} . \nu_{\mathrm{m}} \times \mathrm{x}$ (Nujol) $1770,1730,1026,983 \mathrm{~cm}^{-1} \quad \mathrm{NMR}\left(100 \mathrm{MHz}, \mathrm{CDCl}_{3}\right)$ ₹ $5.30(1 \mathrm{H}, \mathrm{m}), 6.10(1 \mathrm{H}, \mathrm{m}), 6.47(2 \mathrm{H}, \mathrm{m}), 9.12(1 \mathrm{H}, \mathrm{s})$. Anal. Found: C, 73.26; $\mathrm{H}, 8.87$. Calcd. for $\mathrm{C}_{22} \mathrm{H}_{32} \mathrm{O}_{4}$ : C, $73.30 ; \mathrm{H}, 8.95 \%$.

( \pm )-3a-Tetrahydropyranyloxy-14, 16-dioxo-17, 19bisnorkatrane $(X I V a)$. XIIIa was worked up as described above to give crystals (XIVa) in $32 \%$ overall yeild from XIa. Recrystallization from ether-ethanol gave leaflets, mp $201 \sim 204^{\circ} \mathrm{C} . \nu_{\mathrm{max}}$ (Nujol) 1770,1745 , $1025,977 \mathrm{~cm}^{-1}$. Anal. Found: C, 73.76; H, 9.15. Calcd. for $\mathrm{C}_{23} \mathrm{H}_{34} \mathrm{O}_{4}: \mathrm{C}, 73.74 ; \mathrm{H}, 9.05 \%$.

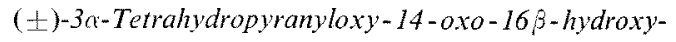
18,19-bisnorkaurane $(X V b)$ and its $C-16$ epimer $\left(X V b^{r}\right)$. To a stirred solution of the Grignard reagent $(15.4 \mathrm{~g}$ of $\mathrm{Mg}, 91 \mathrm{~g}$ of $\mathrm{Mel}$, and $500 \mathrm{ml}$ of dry ether), XIVb $(23 \mathrm{~g})$ in dry THF $(500 \mathrm{ml})$ was added dropwise under $\mathrm{N}_{2}$ atmosphere at $5 \sim 10^{\circ} \mathrm{C}$. After $3 \mathrm{hr}$ stirring at room temperature, sat $\mathrm{NH}_{4} \mathrm{Cl}$ aq. $(130 \mathrm{ml})$ was added slowly to the reaction mixture cooled by ice-salt. After $1 \mathrm{hr}$ cold water was added. The reaction mixture was extracted with ether. The ether extract was washed with water and brine, dried $\left(\mathrm{Na}_{2} \mathrm{SO}_{4}\right)$ and concentrated to give crude crystals. These were triturated with ether-pet. ether to give $13 \mathrm{~g}$ of crystals (XVIb). The residual was chromatographed on alumina. Elution with benzene-AcOEt $(9: 1)$ afforded further amount of 
$\mathrm{XVb}(6.0 \mathrm{~g}) . \quad y_{\mathrm{m} a x}$ (Nujol) $3520,1738,1130,1120$, $1024,984 \mathrm{~cm}^{-1}$ And the latter elution gave $\mathrm{XVb}^{\prime}$ $(2.1 \mathrm{~g}) . \nu_{\mathrm{max}}$ (Nujol) $3390,1728,1115,1046,1025 \mathrm{~cm}^{-1}$. These were employed for the next reaction without further purification.

(-) -3a-Tetrahydropyranyloxy-14-0xo-16, $3-$ hydroxy19-norkawane $(X \mid a)$ and its $C-16$ epimer $\left(X V a^{\prime}\right)$. The Grignard reaction of XIVa as described above gave a mixture of $\mathrm{XVa}$ and $\mathrm{XVa}$. These were separated by chromatography on alumina. The fractions eluted with benzene gave crystals of XVa $(81 \%$ yield) which were recrystallized from ether-pet. ether, mp 180 $182^{\circ} \mathrm{C}$. $\nu_{\mathrm{m}} \mathrm{x}$ (Nujol) $3460,1740,1130,1077,1020$, $978 \mathrm{~cm}^{-1}$ Anal. Found: C, 73.68; H, 9.68. Calcd. for $\mathrm{C}_{24} \mathrm{H}_{38} \mathrm{O}_{4}: \mathrm{C}, 73.80 ; \mathrm{H}, 9.81$. The fractions eluted with benzene-AcOEt $(19: 1)$ gave its C-16 epimer $\left(12 \%\right.$ yield). $\nu_{\max }$ (Nujol) $3550,1737,1040$, $1010,960 \mathrm{~cm}^{-1}$.

Ethylidene formation of $X \mathrm{Vb}^{\prime}$. To a solution of liquid $\mathrm{NH}_{3}(50 \mathrm{ml})$ and $\mathrm{Li}(200 \mathrm{mg}), \mathrm{XVb}^{\prime}(1.0 \mathrm{~g})$ in dry THF $(50 \mathrm{ml})$ was added with stirring at $-60 \sim$ $-40^{\circ} \mathrm{C}$. One hour later, $\mathrm{NH}_{4} \mathrm{Cl}(6 \mathrm{~g})$ was added to the reaction mixture at $-60 \sim-40 \mathrm{C}$. The reaction mixture turned from deep-blue to white. After the evaporation of $\mathrm{NH}_{3}$ at room temperature, it was diluted with sat $\mathrm{NH}_{4} \mathrm{Cl}$ aq. $(40 \mathrm{ml})$ and extracted with ether. The organic layer was washed with brine and dried $\left(\mathrm{MgSO}_{4}\right)$. Evaporation of ether gave an oily mixture $(1.0 \mathrm{~g})$, to which $99 \%$ acetaldehyde $(15 \mathrm{ml})$ and $\mathrm{ZnCl}_{2}(1.0 \mathrm{~g})$ was added. After $20 \mathrm{hr}$ stirring at room temperature, the reaction mixture was diluted with dil. $\mathrm{NaHCO}_{3} \mathrm{aq}$, and extracted with ether. The organic layer was washed with water and brine, dried $\left(\mathrm{Na}_{2} \mathrm{SO}_{4}\right)$. Evaporation of ether in vacto gave an oily mixture of XVIII, XIX and XX, which was chromatographed on alumina $(20 \mathrm{~g})$. The fraction (No. $1 \sim 3)$ eluted with $n$-hexane-benzene $(1: 1)(100 \mathrm{ml} 3)$ gave crystals $(150 \mathrm{mg})$ of XVIII, mp $162-165^{\circ} \mathrm{C}$ (from acetone). $\nu_{\mathrm{wu}}$ (Nujol) $1113,1020,963 \mathrm{~cm}^{-1}$ NMR $\left(100 \mathrm{MHz}, \mathrm{CDCl}_{3}\right)=4.81(1 \mathrm{H}, \mathrm{q}, J=5 \mathrm{~Hz})$, $5.30(\mathrm{HH}), 5.70(\mathrm{C}-14 \mathrm{H}, \mathrm{s}), 6.14(1 \mathrm{H}, \mathrm{m}), 6.48(2 \mathrm{H}, \mathrm{m})$, $8.70(3 \mathrm{H}, \mathrm{s}), 8.73(3 \mathrm{H}, \mathrm{d}, J=5 \mathrm{~Hz}), 9.12(3 \mathrm{H}, \mathrm{s})$. Anal. Found: $\mathrm{C}, 74.14 ; \mathrm{H}, 10.13$. Calcd. for $\mathrm{C}_{25} \mathrm{H}_{10} \mathrm{O}_{4}$ : C. $74.21 ; \mathrm{H}, 9.97 \%$ The fraction (No. 4) eluted with benzene $(100 \mathrm{ml})$ gave an oil $(70 \mathrm{mg})$. The fractions (No. $5 \sim 9$ ) eluted with benzene $(100 \mathrm{ml}$ 5) gave crystals $\left(210 \mathrm{mg}\right.$ ) of XIX, mp $157-159^{\circ} \mathrm{C}$. $\nu_{\mathrm{m}: \mathrm{x}}$ (Nujol) $3300,1150,1000,1052,1029,946 \mathrm{~cm}^{-1}$. NMR $\left(100 \mathrm{MHz}, \mathrm{CDCl}_{3}\right)=4.82(1 \mathrm{H}, \mathrm{q}, J=5 \mathrm{~Hz}), 5.71(\mathrm{C}-$ $14 \mathrm{H}, \mathrm{s}), 4.45(1 \mathrm{H}, \mathrm{m}), 8.73(3 \mathrm{H}, \mathrm{s}), 8.74(3 \mathrm{H}, \mathrm{d}, J=$ $5 \mathrm{~Hz}$ ), (There is NOE of $20+2 \%$ between $\mathrm{C}-10$ methyl and $\mathrm{C}-14$ hydrogen.). Anal. Found: $\mathrm{C}, 74.69 ; \mathrm{H}$, 10.39. Calcd. for $\mathrm{C}_{20} \mathrm{H}_{32} \mathrm{O}_{3}: \mathrm{C}, 74.96 ; \mathrm{H}, 10.06 \%$. The fraction (No. 10) eluted with benzene-MeOH $(9: 1)(100 \mathrm{ml})$ gave crystals $(30 \mathrm{mg})$ of $\mathrm{XX}, \mathrm{mp} 224.5 \sim$ $225.5^{\circ} \mathrm{C}$ (from EtOAc-ether). $\nu_{\mathrm{m} x \mathrm{x}}$ (Nujol) $3400 \sim 3300$, $1125,1055,1032,966 \mathrm{~cm}^{-1}$. NMR $\left(100 \mathrm{MHz}, \mathrm{C}_{5} \mathrm{D}_{5} \mathrm{~N}\right)$ - $3.79(\mathrm{C}-14 \mathrm{OH}, \mathrm{d}, J=6 \mathrm{~Hz}$, coupling with $\mathrm{C}-14 \mathrm{H})$, $4.09(\mathrm{C}-16 \mathrm{OH}, \mathrm{s}), 4.18(\mathrm{C}-3 \mathrm{OH}, \mathrm{d}, J=2 \mathrm{~Hz}$ coupling with $\mathrm{C}-3 \mathrm{H}), 5.57(\mathrm{C}-14 \mathrm{H}, \mathrm{d}, J=6 \mathrm{~Hz}, 16 \pm 2 \% \mathrm{NOE}$ with $\mathrm{C}-10$ methyl), $6.16(\mathrm{C}-3 \mathrm{H}, \mathrm{m}), 8.47\left(\mathrm{C}-16 \mathrm{CH}_{3}\right.$, s), $9.09\left(\mathrm{C}-10 \mathrm{CH}_{3}\right.$, s). Anal. Found: C, 73.09; $\mathrm{H}, 10.32$. Calcd. for $\mathrm{C}_{18} \mathrm{H}_{30} \mathrm{O}_{3}: \quad \mathrm{C}, 73.43 ; \mathrm{H}, 10.27 \%$. The fractions (No. $11 \sim 14$ ) eluted with benzene-MeOH $(9: 1)$ gave an oil $(280 \mathrm{mg})$.

(士)-3a, 16ק-Dihydroxyl-14-oxo-18, 19-bisnorkaurane $(X V / b)$. To a solution of XVb (13.0 g) in THF $(240 \mathrm{ml}), \mathrm{AcOH}-\mathrm{H}_{2} \mathrm{O}(2: 1)(720 \mathrm{ml})$ was added. The mixture was stirred for $20 \mathrm{hr}$ at room temperature and then for $3 \mathrm{hr}$ at $40^{\circ} \mathrm{C}$. The reaction mixture was concentrated in vacuo and extracted with ether. The ether extract was washed with sat $\mathrm{NaHCO}_{3}$ aq. and brine, and dried $\left(\mathrm{MgSO}_{4}\right)$. Evaporation of ether gave crystals $(10.0 \mathrm{~g})$, which were recrystallized from EtOAc, mp $215 \sim 216^{\circ} \mathrm{C} . \quad \nu_{\max }$ (Nujol) $3400,1730,1125,1026$, $943 \mathrm{~cm}^{-1}$. Anal. Found: C, 73.88; H, 9.57. Cacld. for $\mathrm{C}_{18} \mathrm{H}_{28} \mathrm{O}_{3}: \quad \mathrm{C}, 73.93 ; \mathrm{H}, 9.65 \%$.

$( \pm)-3 a-16 a-D i h y d r o x y-14-0 x 0-18,19-b i s n o r k a t r a n e$ $\left(X V I b^{\prime}\right) . \quad \mathrm{XVb}^{\prime}$ was worked up as described above to give crystals. Recrystallization from EtOAc gave needles, $\mathrm{mp} 207 \sim 211 \mathrm{C}, \nu_{\mathrm{max}}$ (Nujol) 3430, 3380, 1732, 1045, 1026, 970, $875 \mathrm{~cm}^{-1}$ NMR $(60 \mathrm{MHz}$, $\left.\mathrm{C}_{5} \mathrm{D}_{5} \mathrm{~N}\right)=8.43(3 \mathrm{H}, \mathrm{s}), 9.09(3 \mathrm{H}, \mathrm{s})$. Anal. Found: C, 73.68; H, 9.43. Calcd. for $\mathrm{C}_{18} \mathrm{H}_{28} \mathrm{O}_{3}:$ C, 73.93; $\mathrm{H}, 9.65 \%$.

(t) 3a, 16,-Dihydroxy-14-oxo-19-norkanrane (XVIa). $\mathrm{XVa}$ was worked up as described above to give crystralline diol XVIa $(83 \%)$, which was recrystallized from ether $\mathrm{MeOH}$, mp $222 \sim 223.5^{\circ} \mathrm{C} . \quad \nu_{\mathrm{m}: \mathrm{x}}$ (Nujol) $3400,1743,1130,1028,955 \mathrm{~cm}^{-1} \quad$ NMR $(100 \mathrm{MHz}$, $\left.\mathrm{CDCl}_{3}\right)=8.91(\mathrm{OH} 2), 7.72(3 \mathrm{H}, \mathrm{s}), 9.00(3 \mathrm{H}, \mathrm{d}$, $J=6 \mathrm{~Hz}), 9.12(3 \mathrm{H}, \mathrm{s})$. Anal. Found: C, 74.14; H, 9.72. Caled. for $\mathrm{C}_{19} \mathrm{H}_{0} \mathrm{O}: \mathrm{C}, 74.47 ; \mathrm{H}, 9.87^{\circ}$.

$(-t)-3,14-$ Dioxo-16,-hydroxy-18,19-bisnorkanane $(X V I I b)$. Jones chromic acid reagent $(15 \mathrm{ml})$ was added to ice-cooled solution of XVIb $(10.0 \mathrm{~g})$ in acetone $(870 \mathrm{ml})$ and the mixture left to stand at room temperature for $10 \mathrm{~min}$. $\mathrm{MeOH}$ was added to destroy the excess of the oxidant. After the removal of the solvents in vacuo, the residue was diluted with water and ex- 
tracted with ether. The ether extract was washed with $\mathrm{NaHCO}_{3}$ aq. and brine. Concentration of the solution after drying $\left(\mathrm{MgSO}_{4}\right)$ gave $9.0 \mathrm{~g}$ of the diketone. Recrystallization from acetone gave needles, $\mathrm{mp}$ 189 $190^{\circ} \mathrm{C}$. $\nu_{\text {max }}$ (Nujol) $3430,1740,1700,1126,953 \mathrm{~cm}^{-1}$ NMR (100 MHz, $\left.\mathrm{CDCl}_{3}\right) \quad 8.13(\mathrm{OH}), 8.75(3 \mathrm{H}, \mathrm{s})$, $9.00(3 \mathrm{H}, \mathrm{s})$. Anal. Found: $\mathrm{C}, 74.26 ; \mathrm{H}, 8.94$. Calcd. for $\mathrm{C}_{18} \mathrm{H}_{{ }_{6}} \mathrm{O}_{3}: \quad \mathrm{C}, 74.44 ; \mathrm{H}, 9.03 \%$.

(+)-3,14-Dioxo-16a-hydroxy-18,19-bisnorkaurane $\left(\mathrm{X}^{\prime} I I b^{\prime}\right)$. XVIb' was worked up as described above to give crystals which were recrystallized from AcOEtbenzene, $m p 200 \sim 203 \% \mathrm{C} . \nu_{\mathrm{m} . \mathrm{x}}$ (Nujol) 3470, 1746, $1705,1138,1045,957,870 \mathrm{~cm}^{-1}$. NMR $(60 \mathrm{MHz}$, $\left.\mathrm{CDCl}_{3}\right)=8.14(\mathrm{OH}), 8.53(3 \mathrm{H}, \mathrm{s}), 9.00(3 \mathrm{H}, \mathrm{s})$. Anal. Found: $\mathrm{C}, 74.42 ; \mathrm{H}, 8.96$. Cacld. for $\mathrm{C}_{18} \mathrm{H}_{26} \mathrm{O}_{3}$ : $\mathrm{C}, 74.44 ; \mathrm{H}, 9.03^{\circ}$ \%

(4)-3,14-Dioxo-16, 9-hydroxy-19-norkaurane (XIIIa) XVIa was worked up as described above to give the diketone in $98 \%$ yield. Recrystallization from $\mathrm{MeOH}$ benzene- $n$-hexane gave prisms, mp $231 \sim 233 \mathrm{C}$. $\nu_{\mathrm{m}: \mathrm{i}}$ (Nujol) $3520,1735,1693,1168,1124,945 \mathrm{~cm}^{-1}$ NMR (100 MHz, $\left.\mathrm{CDCl}_{3}\right) \quad 8.20(\mathrm{OH}), 8.72(3 \mathrm{H}, \mathrm{s})$, $8.91(3 \mathrm{H}, \mathrm{s}), 8.97(3 \mathrm{H}, \mathrm{d}, J=6.5 \mathrm{~Hz})$. Anal. Found: C, 74.95; $\mathrm{H}, 9.13$. Calcd. for $\mathrm{C}_{19} \mathrm{H}_{28} \mathrm{O}_{3}:$ C, 74.96; $\mathrm{H}, 9.27 \%$.

\section{REFERENCES}

1) K. Mori and M. Matsui, Tetrahedron, 24, 3095 (1968).

2) K. Mori, M. Shiozaki, N. Itaya, M. Matsui and Y. Sumiki, ibid., 25, 1293 (1969).

3) a) Y. Nakahara, K. Mori and M. Matsui, Agr. Biol. Chem., 35, 918 (1971).

b) K. Mori, Y. Nakahara and M. Matsui, Tetrahedron, 28, 3217 (1972).

4) M. Shiozaki, K. Mori, M. Matsui and T. Hiraoka, Tetrahedron Lett., 1972, 657.

5) J. W. Cornforth and R. Robinson, J. Chem. Soc., 1949, 1855.

6) G. Stork, A. Meisels and J. E. Davies, J. Am. Chem. Soc., 85, 3419 (1963).

7) R. L. Augustine, J. Org. Chem., 23, 1853 (1958).

8) G. Stork and S. D. Darling, J. Am. Chem. Soc., 86, 1761 (1964).

9) R. E. Ireland and J. A. Marshall, J. Org. Chem., 27, 1615 (1962).

10) R. Pappo, D. S. Allen, Jr., R. U. Lemieux and W. S. Johnson, ibid., 21, 478 (1956). 